\title{
Cases of Subclinical Mastitis in Dairy Cattle, Microbiological Quality and Residues of Antibiotic Cow's Milk: A Case Study in Tanggamus District
}

\author{
Veronica Wanniatie ${ }^{1, *}$, Arif Qisthon ${ }^{1}$, Purnama Edy Santosa ${ }^{1}$, Dian Cahya Hadi ${ }^{1}$, \\ Oktora Luhur Handika ${ }^{1}$, Ammar Naupal Shodiq ${ }^{1}$, and Dedy Yuliawan ${ }^{2}$
}

\author{
${ }^{1}$ Department Animal Husbandry, Faculty of Agriculture, University of Lampung, Indonesia, 35145 \\ ${ }^{2}$ Department of Economics, Faculty of Economics and Business, University of Lampung, Indonesia, 35145 \\ *Corresponding author. Email: veronica.wanniatie@fp.unila.ac.id
}

\begin{abstract}
The aim of this study was to determine cases subclinical mastitis in dairy cattle, microbiological quality and residues of antibiotic cow's milk from dairy farm in Tanggamus District. This research was conducted in January 2020 in Tanggamus District, Lampung Province. The milk samples used in this study were individual samples from all lactating cows, as many as 19 samples from 2 districts, namely Gisting Sub District and Air Naningan Sub District. The tests carried out were the somatic cells count (SCC) using the Breed method and mastitis IPB-1 test, total plate count (TPC), Staphylococcus aureus, coliform and Escherichia coli, density, $\mathrm{pH}$ values and antibiotic residue testing using Screening test/Bioassay. The data obtained were analyzed descriptively. The results of the study on SCC showed that Gisting Sub District had higher SCC than Air Naningan Sub District, which was > 400,000 cells $/ \mathrm{ml}$ $(2,554,285 \mathrm{cells} / \mathrm{ml})$ and was supported by the IPB-1 mastitis test, which was $33.33 \%$ the teats that were positive for mastitis subclinical. The test results on TPC and E. coli showed that Air Naningan Sub District had higher TPC and E. coli values than Gisting Sub District, which were $3.39 \mathrm{log} \mathrm{cfu} / \mathrm{ml}$ and $0.8 \mathrm{log} \mathrm{cfu} / \mathrm{ml}$, respectively. Meanwhile, the test results for the presence of S. aureus and coliform bacteria showed that Gisting Sub District had higher levels of S. aureus and coliform bacteria than Air Naningan Sub District, which were $0.32 \log \mathrm{cfu} / \mathrm{ml}$ and $2.36 \log \mathrm{cfu} / \mathrm{ml}$, respectively. The results of density and $\mathrm{pH}$ values in 2 sub-districts showed almost the same, namely 1.030 and 6.88 . The results of the Bioassay screening test for antibiotic residues in cow's milk in Tanggamus District showed that there were no samples containing penicillin, tetracycline, aminoglycoside, and macrolide antibiotic residues. The conclusion of this study was that there were cases of subclinical mastitis in dairy farms in Gisting and Air Naningan Districts based on the presence of SCC in milk and no antibiotic residue was found in milk.
\end{abstract}

Keywords: Antibiotic residues, Milk cow's, Mastitis test, Microbiology.

\section{INTRODUCTION}

Recently, supply and demand for dairy products in Indonesia is still in a deficit condition. Indonesia's local milk production is still limited and depends on milk imports, however, the consumption of milk and dairy products continues to increase rapidly in the last decade. Lampung Province is also experiencing a shortage of cow's milk production compared to demand. Tanggamus district is one of 3 disricss in Lampung Province where dairy cows can be found. The population of dairy cattle in this district is less than 50 heads spread over the districts of Air Naningan and Gisting

Cow's milk contributes to the fulfillment of animal protein needs for humans, especially children. Cow's milk must contain good nutritional value and do not contain ingredients that can harm consumers. Harmful substances contained in milk can come from biological contaminants and chemical contaminants. Milk can contain biological contaminants because it is contaminated from the udder and the environment. Biological contamination comes from microbes and protozoa [1]. Milk can also contain chemical 
contaminants from antibiotic residues, pesticide residues, and heavy metal residues [2]. Chemical contamination in the form of residue comes from the treatment of cattle with mastitis, feed containing pesticide residues, water and the environment contaminated with heavy metals.

Biological and chemical contaminants contained in cow's milk either due to contamination from the environment or from the body of livestock will cause health problems for consumers. Currently, data regarding biological and chemical contamination of cow's milk in Lampung Province, especially in Tanggamus District is not yet available, so research is needed to obtain these data. The aim of this study was to determine cases subclinical mastitis in dairy cattle, microbiological quality and residues of antibiotic cow's milk from dairy farm in Tanggamus District.

\section{MATERIALS AND METHODS}

\subsection{Sample collections}

The milk sample used in this study was an individual sample of 19 samples taken from 19 lactating dairy cows kept in Tanggamus District. This research was conducted in January 2020. This study was conducted in a cross sectional manner with census sampling. Milk samples were collected from dairy cows during normal lactation. Every $100 \mathrm{~mL}$ of milk was collected in sterile glass bottles and transferred to laboratory under cool condition. All samples were analyzed immediately at the Lampung Veterinary Center Laboratory and the Animal Production Laboratory, Faculty of Agriculture, University of Lampung.

\subsection{Procedures}

\subsubsection{Subclinical mastitis test}

Examination of milk samples for the diagnosis of subclinical mastitis is done by counting the number of somatic cells in milk. The somatic cells count (SCC) was counted directly and indirectly. Direct examination using the Breed method, namely SCC directly using a microscope and indirect examination using the IPB-1 mastitis test, namely to see the reaction formed between IPB-1 reagent and milk [3].

The breed method used refers to [4]. The slide is cleaned with $70 \%$ alcohol solution and placed on printed paper or a square pattern measuring $1 \mathrm{x} 1 \mathrm{~cm} 2$. The milk being examined is homogenized first, then the milk is pipetted using a Breed pipette and $0.01 \mathrm{~mL}$ of milk is dripped just above the $1 \mathrm{~cm} 2$ box. Milk samples were stocked in $1 \mathrm{~cm} 2$ squares using elbow-tipped ossicles. The slides were dried in air for 5-10 minutes and then fixed with a Bunsen flame.
Breed staining was done after the milk sample on the glass object was dry. The slides were immersed in an alcohol ether solution for two minutes, then the slides were stained by immersing them in Löffler's methylene blue solution for 1-2 minutes. The slides were immersed in a $96 \%$ alcohol solution for one minute to remove the remaining dye adhering to them. After the coloring process is complete, the slide is dried using filter paper. SCC was carried out after the preparations were dried using a microscope (objectively 100 times) which had previously been dripped with immersion oil. SCC was calculated using 10 fields of view, then the somatic cells were summed and divided by the number of fields of view to determine the average SCC. After knowing the average SCC, the calculation is carried out using the formula:

The IPB-1 mastitis test method used refers to [4] 2 $\mathrm{mL}$ of milk sample was put into the paddle, then $2 \mathrm{~mL}$ of IPB-1 reagent was added. The mixture of milk sample and IPB-1 reagent was homogenized horizontally for 15-30 seconds. IPB-1 reagent reacts with DNA from the nucleus of somatic cells, producing a viscous mass like gelatin. The results are read based on the reaction that occurs, namely the formation of mucus or changes in viscosity with a negative value (-) if it remains homogeneous and positive $(+,++,+++)$ if mucus is formed or thickens.

\subsubsection{Total Plate Count (TPC)}

Calculating the TPC was done by using the official methods of AOAC (2016) with plate count. Samples of milk were taken $1 \mathrm{~mL}$, then was diluted using a $0.1 \%$ buffer peptone water (BPW, OXOID Ltd., Basingstoke, UK) up to 10-6 dilution. Furthermore, from each dilution was taken $0.01 \mathrm{~mL}$ was then inserted into sterile petri dish, then poured the liquid medium plate count agar (PCA; OXOID Ltd., Basingstoke, UK. and homogenized by means of shifting the plate horizontally or a figure number of eight and allowed to clot. The next stage was incubated at $37^{\circ} \mathrm{C}$ for $24-48$ hours and all colonies were counted as TPC.

\subsubsection{Counting the Number of Staphylococcus aureus)}

Counting the number of S. aureus was done by official methods of AOAC (2016). Samples of milk was taken $1 \mathrm{~mL}$, then diluted with $0.1 \%$ of BPW up to $10-6$ dilution. Furthermore, from each dilution was taken $0.01 \% \mathrm{~mL}$ to put into a sterile petri dish, then poured the liquid medium mannitol salt agar (MSA; OXOID Ltd., Basingstoke, United Kingdom). Furthermore homogenized by sliding horizontally or a figure of eight, and if it has been frozen incubated at $37^{\circ} \mathrm{C}$ for $24-48$ hours. The form of counted colony was round, slippery, and yellow. 


\subsubsection{Counting the Number of Coliform}

The number of coliform were counted by using official methods of AOAC (2016). Samples of milk was taken $1 \mathrm{~mL}$, then diluted with $0.1 \%$ BPW up to $10-6$ dilution. Furthermore, from each dilution was taken $0.01 \mathrm{~mL}$ to be put into sterile petri dish, then poured the liquid medium violet red bile agar (VRBA; OXOID Ltd., Basingstoke, United Kingdom). Furthermore, it was homogenized by sliding horizontally or moved it to make a figure number of eight and allowed to be jellylike, then poured VRBA media on the surface of agar (overlay) and incubated at $37^{\circ} \mathrm{C}$ for $24-48$ hours. Counted colony was purplish red colonies surrounded by a red zone. Examination of Escherichia coli was conducted by the isolation and identification. Samples of milk was taken $1 \mathrm{~mL}$, added in $10 \mathrm{~mL}$ of buffer solution peptone water (BPW; OXOID Ltd., Basingstoke, United Kingdom) and then incubated at $37^{\circ} \mathrm{C}$ for 24 hour. The sample were sub cultured on media eosin methylene blue agar (EMBA; OXOID Ltd., Basingstoke, United Kingdom) and incubated at $37^{\circ} \mathrm{C}$ for 24 hours. Colonies that appeared metallic in the EMBA media were Gram stained and the colonies were biochemically tested for E. coli identification.

\subsubsection{Antibiotic Residue Test (Screening Test / Bioassay)}

All samples were tested using the triple bioassay method. The testing method used in this research is the bioassay screening test method for antibiotic residues in milk which refers to SNI No. 7424:2008. The testing stages consist of preparation, testing, and reading the results. Preparation, including preparation of agar media, culture media, buffer solutions, and standard solutions. The bioassay test was aimed at four classes of antibiotics, namely tetracycline, macrolide, aminoglycoside, and penicillin.

The stages of testing antibiotic residues on goat's milk with this method are that the homogenized milk sample is dripped on a paper disc then the paper disc is affixed to the surface of the agar media which has been mixed with the test bacterial culture and incubated at a certain temperature (depending on the type of antibiotic to be tested) for 16-18 hours. The goat's milk sample tested positive for antibiotic residue when a zone of inhibition was formed around the paper disc.

Culture media were prepared for each class of antibiotics. Each petri dish contains 5 sheets of disc paper, consisting of 3 discs each containing $75 \mu l$ of the sample to be analyzed, 1 paper containing $75 \mu \mathrm{l}$ of reference standard solution as a positive control, and one paper dripping with phosphate buffer solution as a control negative. Disc paper is placed on the surface of the culture medium. Petri dishes were covered and incubated at different temperatures depending on the class of antibiotics. The culture medium for the tetracycline group was incubated at $30^{\circ} \mathrm{C} \pm 1$, the penicillin group at $55^{\circ} \mathrm{C} \pm 1$, while the macrolides and aminoglycosides were incubated at $36^{\circ} \mathrm{C} \pm 1$, each for 16-18 hours. To obtain accurate data, the sample was tested with three repetitions so that each type of antibiotic group used three petri dishes.

The results were read by observing and measuring the diameter of the inhibition zone formed around the paper disc using a caliper. The sample was tested positive for antibiotics if the inhibition zone formed was $2 \mathrm{~mm}$ from the edge of the paper disc. The sample was declared negative if the inhibition zone formed was 0-2 $\mathrm{mm}$. Because the inhibition zone formed $<2 \mathrm{~mm}$ was considered due to the presence of natural inhibitors. The diameter of the inhibition zone in the positive control was $20 \pm 1 \mathrm{~mm}$, while the negative control did not form an inhibition zone [5].

\subsection{6. $p H$ value)}

The $\mathrm{pH}$ of pasteurized goat's milk was measured using a pH meter (Jenway model 3520).

\subsection{Statistical Analysis}

The test data were analyzed descriptively which were presented in the form of tables and figures [6].

\section{RESULTS AND DISCUSSION}

\subsection{The Somatic Cells Count (SCC)}

The results of subclinical mastitis and SCC tests in Gisting Atas and Air Naningan sub-districts are presented in Table 1. The results of the research on mastitis testing in Gisting Sub District, from a total of 36 nipples from 9 cows, 12 nipples $(33 \%)$ were positive for subclinical mastitis, while in Air Naningan Sub District there were 40 cows, the nipples of 10 cows tested for mastitis contained 15 nipples $(37 \%)$ positive for subclinical mastitis. The average SCC in dairy cattle in the Gisting Sub District was 2.34 x 106 cells/mL, while in the Air Naningan Sub District it was 8.21 x 105 cells/mL. This SCC is declared not to meet the quality requirements of fresh milk based on SNI 3141.1, which is $4.0 \times 105$ cells $/ \mathrm{mL}$ [7].

Many risk factors have been identified from subclinical mastitis because this disease has multifactorial causes, including a combination of exposure to pathogenic microbial factors in the surrounding environment with different responses of individual livestock [8]. Identification of these factors is very important for the development of methods of prevention and control of subclinical [9]. The high content of SCC in milk causes a decrease in milk 
Table 1. The subclinical mastitis dan somatic cells count (SCC) in cow's milk in Tanggamus District

\begin{tabular}{|c|c|c|c|c|}
\hline \multirow{2}{*}{ Reaction Rate } & \multicolumn{2}{|c|}{$\begin{array}{c}\text { Sub District Gisting } \\
\text { ( } \mathrm{n}=36 \text { nipple) }\end{array}$} & \multicolumn{2}{c|}{$\begin{array}{c}\text { Sub District Air Naningan } \\
(\mathrm{n}=40 \text { nipple) }\end{array}$} \\
\cline { 2 - 5 } & IPB-1 Test & $\mathrm{x}$ SCC (cell/mL) & IPB-1 Test & $\mathrm{x}^{-}$SCC (cell/mL) \\
\hline Negative (-) & 24 & 0 & 25 & 0 \\
\hline Positive 1 (+) & 0 & 0 & 12 & $9.8 \times 105$ \\
\hline Positive 2 (++) & 4 & $1.18 \times 106$ & 1 & $1.92 \times 106$ \\
\hline Positive 3 (+++) & 8 & $3.21 \times 106$ & & \\
\hline
\end{tabular}

quality. Basically, milk that has a high SCC is caused by the large number of pathogenic microbes that damage the inner udder. Microbes that enter the milk ducts will multiply, resulting in an increase in the number of microbes. This increase in the number of microbes will cause the livestock body to produce more leukocytes to fight microbial infections. This is in accordance with the opinion of [10] which states that neutrophils will enter the udder gland to fight microbial infections so that the release of somatic cells in milk will also increase.

An increase in the number of somatic cells indicates the level of inflammation in the udder. This can occur with the possibility of livestock experiencing heat stress. One of the factors that most often causes an increase in the number of somatic cells is heat stress. The heat stress can increase the number of somatic cells and decrease milk quality. Various other factors that can increase the number of somatic cells (SCC) are nutritional deficiencies, as well as poor milking methods.

\subsection{Microbiological Quality}

The results of testing on the content of microorganisms in cow's milk in Gisting and Air Naningan sub-districts (Table 2.) showed that TPC and S. aureus were still below SNI 3141.11, namely <6.0 log $\mathrm{cfu} / \mathrm{mL}$ and $2.0 \log \mathrm{cfu} / \mathrm{mL}$. The count of coliforms in the two sub-districts showed a higher value than SNI 3141.11, which was $1.0 \mathrm{log} \mathrm{cfu} / \mathrm{mL}$. The coliform content after going through a biochemical confirmation test showed the presence of E. coli bacteria in cow's milk. Milk samples from Gisting and Air Naningan subdistricts had good density and $\mathrm{pH}$ values.

Fresh cow's milk contains microorganisms that can come from the cow's body and the environment. According to [11] cow's milk contains coliform bacteria, S. aureus, Enterobacter aerogenes and Proteus vulgaris. TPC is the best way to assess milk management and quality by calculating the bacterial density in milk and estimating the count of aerobic bacteria. The TPC value

Table 2. Average number of microorganisms and physical properties of cow's milk in Tanggamus District

\begin{tabular}{|l|c|c|}
\hline \multirow{2}{*}{\multicolumn{1}{c|}{ Parameter }} & \multicolumn{2}{|c|}{ Sub Distict } \\
\cline { 2 - 3 } & $\begin{array}{c}\text { Gisting } \\
(\mathrm{n}=9)\end{array}$ & $\begin{array}{c}\text { Air Naningan } \\
(\mathrm{n}=10)\end{array}$ \\
\hline TPC $(\log \mathrm{cfu} / \mathrm{ml})$ & 2.88 & 3.39 \\
\hline S. aureus $(\log \mathrm{cfu} / \mathrm{ml})$ & 0.32 & 0.14 \\
\hline Koliform $(\log \mathrm{cfu} / \mathrm{ml})$ & 2.36 & 1.43 \\
\hline E. coli $(\log \mathrm{cfu} / \mathrm{ml})$ & 0.48 & 0.80 \\
\hline Density & 1.03 & 1.03 \\
\hline pH & 6.88 & 6.89 \\
\hline
\end{tabular}


can be high if contamination occurs from milking equipment, dirty udders, and the cow has subclinical or clinical mastitis [12]. The number of microorganisms in milk is a major factor in determining the quality of milk. This shows the level of cleanliness during milking, the cleanliness of milking equipment, the condition of the cage, and the cleanliness of the udder before milking [13]. The same thing was also stated by [14] that the presence of microorganisms in fresh milk is an indicator of the practice of handling milk from the cage until it is consumed by the community so that it greatly determines the quality of milk. Bacterial contamination can enter from the udder, cage environment, milk collection bucket, and milker's hand.

$\mathrm{S}$. aureus is a commensal bacteria that is commonly

\subsection{Residues of Antibiotic}

The results of the Bioassay screening test for antibiotic residues in cow's milk in Tanggamus District (Tabel 3.) showed that there were no samples containing penicillin, tetracycline, aminoglycoside, and macrolide antibiotic residues. This indicates that breeders do not treat subclinical mastitis. Antibiotics in livestock are not only used as mastitis therapy, but also to control, prevent disease and are intended to increase growth and feed efficiency. Inappropriate use of antibiotics can lead to antibiotic resistance of pathogenic bacteria and contribute to a global health crisis. The presence of antimicrobial residues in milk can cause hypersensitivity reactions to drugs in consumers such as

Table 3. Residues of cow's milk antibiotics in Tanggamus District

\begin{tabular}{|l|c|c|}
\hline \multirow{2}{*}{ Antibiotic residues (\%) } & \multicolumn{2}{|c|}{ Sub District } \\
\cline { 2 - 3 } & $\begin{array}{c}\text { Gisting } \\
(\mathrm{n}=9)\end{array}$ & $\begin{array}{c}\text { Air Naningan } \\
(\mathrm{n}=10)\end{array}$ \\
\hline Penicillin & Negative & Negative \\
\hline Tetracycline & Negative & Negative \\
\hline Aminoglycoside & Negative & Negative \\
\hline Macrolide & Negative & Negative \\
\hline
\end{tabular}

found in the udder and the environment. The presence of $\mathrm{S}$. aureus in cage milk was associated with mastitis, cage age and high milk production [12]. S. aureus is the main agent of mastitis in dairy cattle and goats [15], and will affect milk production and the somatic cell count (SCC). S. aureus can spread easily from animal to animal via milking machines or hand milking.

Coliform bacteria are almost always found in fresh milk. Coliform bacteria and E.coli are thermoduric bacteria originating from livestock, especially feces and environmental conditions that can contaminate milk [16]. The presence of coliforms such as E. coli and Klebsiella spp. in milk indicates contamination that can occur from the environment and dirty equipment [11] and can come from cows infected with mastitis [12]. E. coli is usually used as an indicator microbe. E. coli is a microbe originating from the digestive tract of humans and animals. These bacteria are used as indicator bacteria because E. coli can survive in water compared to other pathogenic bacteria [17]. dermal reactions, asthma or anaphylaxis [18].

The presence of antibiotic residues can also cause obstacles in the processing of other dairy products and in the end will cause antibiotic resistance to pathogenic bacteria so that it will become a global health crisis [19; 20]. Tetracyclines are used globally in veterinary medicine as broad-spectrum antibiotics for the treatment of gram-negative aerobic and anaerobic bacteria. Tetracyclines, including chlortetracycline, are routinely used to prevent and treat mastitis in dairy cattle [21] Macrolides are often used in the treatment of mastitis in cattle [22]. The most commonly used macrolides are erythromycin, spiramycin, and tylosin [21].

\section{CONCLUSION}

Based on the research that has been done, it can be concluded that there are cases of subclinical mastitis in dairy farms in Gisting and Air Naningan Districts based on the presence of SCC in milk and no detectable antibiotic residue in milk, which indicates that farmers do not treat subclinical mastitis infection in they dairy cattle. 


\section{REFERENCES}

[1] Wanniatie V, M B Sudarwanto, T Purnawarman and A Jayanegara 2019 Comparison of microbiological quality between organic and conventional goat milk: A study case in Bogor Indonesia. Adv. Anim. Vet. Sci. Vol 7 No 7 p 593-598.

[2] Wanniatie V, M B Sudarwanto, T Purnawarman, and A Jayanegara 2019 Chemical compositions, contaminants, and residues of organic and conventional goat milk in Bogor District Indonesia. Veterinary World Vol 12 No 8 p 1218-1224.

[3] Sudarwanto M B, H Maheswari and F Tanjung 2016 The equality of ipb-1 mastitis test with breed method for sub-clinical mastitis detection on murrah buffalo's milk and goat's milk. J Veteriner Vol 17 No 4 p 540-547

[4] Lukman DW, M Sudarwanto, A W Sanjaya, T Purnawarman, H Latif, RR Soejoedono 2012 Subclinical Mastitis Examination In: H Pisestyani (Ed). Food Hygiene of Animal Origin. Bogor: Kesmavet FKH IPB p 35-38

[5] Badan Standarisasi Nasional 2008. SNI 7424:2008: Screening test Antibiotic Residues in Meat, Eggs and Milk by Bioassay Jakarta (ID): BSN

[6] Sugiyono 2015 Nonparametric Statistics for Research Bandung: Alfabeta

[7] Indonesia National Standard 2011 Fresh Milk-Part 1: Cows Indonesia. National Standard, Indonesia

[8] Wicaksono A and M Sudarwanto 2016 Subclinical mastitis prevalence and milk microbiological evaluation on small scale dairy farms in Boyolali. Acta Veterinaria Indonesiana Vol. 4 No 2 p 51-56

[9] Bastan A, C Salar, M Cengiz, I Darbaz, M Demirel, and D Ozen 2015 The prediction of the prevalence and risk factors for subclinical heifer mastitis in Turkish dairy farms. Turkish Journal of Veterinary and Animal Sciences Vol 39 p 682-687.

[10] Sudarwanto M dan E Sudarnika 2008 The relationship between milk $\mathrm{pH}$ and the number of somatic cells as a parameter of subclinical mastitis. J. Media Peternakan Vol 31 No 1 p 107-113

[11] Iqbal H, M Ishfaq, M N Abbas, A Wahab, M Qayum, and S Mehsud 2016 Pathogenic bacteria and heavy metals toxicity assessments in evaluating unpasteurized raw milk quality quality through biochemical tests collected from dairy cows. Asian Pacific J. Trop. Dis. Vol. 6 no $11 \mathrm{p}$ 868-872.

[12] Cicconi-Hogan K M, M Gamroth, R Richert, P L Ruegg, K E Stiglbauer, and Y H Schukken 2013
Risk factors associated with bulk tank standard plate count, bulk tank coliform count, and the presence of Staphylococcus aureus on organic and conventional dairy farms in the United States. J. Dairy Sci. Vol 96 No 12 p 7578-7590

[13] Tassew A and E Seifu 2011 Microbial quality of raw cow's milk collected from farmers and dairy cooperatives in Bahir Dar Zuria and Mecha district, Ethiopia. Agriculture and Biology Journal of North America Vol 2 p 29-33

[14] Mesfine S, T Feyera, O Mohammed 2015 Microbiological quality of raw cow's milk from four dairy farms in Dire Dawa City, Eastern Ethiopia. World Journal of Dairy \& Food Sciences Vol 10 p 9-14

[15] Prasetyo B W, Sarwiyono and P Surjowardojo 2013 The relationship between the diameter of the nipple hole and the incidence of mastitis. J Ternak Tropika Vol 14 No 1 p 15-20

[16] Suwito W 2010. Bacteria that often contaminate milk: Detection, pathogenesis, epidemiology, and how to control it. Jurnal Litbang Pertanian Vol 29 No 3 p 96-100

[17] Sudarwanto M. 2012. Handbook: Examination of Milk and Its Processed Products. Bogor (ID): IPB Press.

[18] Rama A, L Lucatello, C Benetti, G Galina and D Bajraktari 2017 Assessment of antibacterial drug residues in milk for consumption in Kosovo. J. Food Drug Anal., Vol 25 No 3 p 525-532

[19] Comunian R, A Paba, I Dupré, E S Daga and M F Scintu 2010 Evaluation of a microbiological indicator test for antibiotic detection in ewe and goat milk. J. Dairy Sci. Vol 93 No 12 p 5644-5650

[20] Pogurschi E, A Ciric, C Zugrav and D Patrascu 2015. Identification of Antibiotic Residues in Raw Milk Samples Coming from the Metropolitan Area of Bucharest. Agric. Agric. Sci. Procedia p 62426245 .

[21] Bilandzic N, B S Kolanovic, I Varenina, G Scortichini, L Annunziata, M Brstilo and N Rudan. 2011 Veterinary drug residues determination in raw milk in Croatia. Food cont. Vol 22 p1941-1948

[22] Berruga M I, A Molina, R L Althaus and M P Molina 2016 Control and prevention of antibiotic residues and contaminants in sheep and goat's milk. Small Rum. Res. Vol 142 p 38-43. [10] B. Meyer, Applying "Design by Contract", Computer 25(10) (1992) 40-51. https://doi.org/10.1109/2.161279 